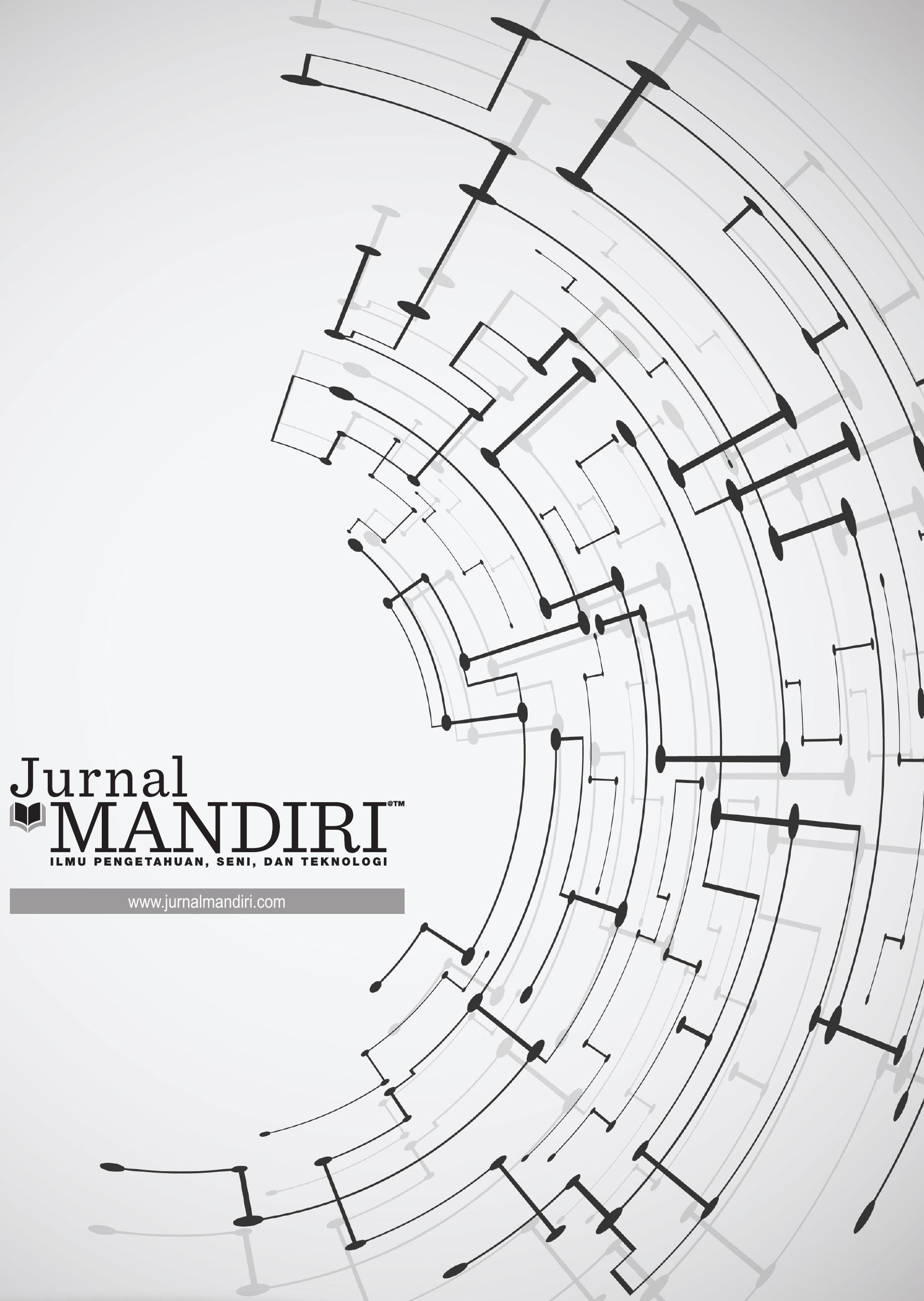


ISSN : 2580-3220, E-ISSN : 2580-4588

J. Mandiri., Vol. 3, No. 2, Desember 2019 (268 - 279)

C2018 Lembaga Kajian Demokrasi

dan Pemberdayaan Masyarakat (LKD-PM)

DOI : https://doi.org/10.33753/mandiri.v3i2.88

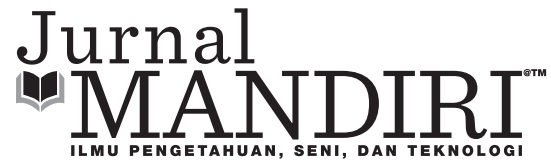

\title{
Pengaruh Lingkungan Sekolah Terhadap Motivasi Warga Belajar Pada Pusat Kegiatan Belajar Masyarakat (PKBM) Cipta Tunas Karya
}

\author{
Ahmad Nazir \\ Fakultas Ekonomi, Universitas Pamulang \\ naziramangkurat@gmail.com
}

\begin{abstract}
Abstrak
Tujuan dilakukan penelitian ini untuk mengetahui bagaimana kondisi Lingkungan sekolah, Bagaimana motivasi warga belajar, dan seberapah besarkah pengaruh Lingkungan sekolah (X) terhadap motivasi warga belajar (Y) PKBM Cipta Tunas Karya. Dengan menggunakan metode penelitian deskriptif kuantitatif, keseluruhan warga belajar Cipta Tunas Karya dijadikan responden dengan jumlah 210 responden, dan sampel yang digunakan adalah rondom sampling sebanyak 90 sampel. Hasil dalam penelitian ini adalah Lingkungan Sekolah (X) belum optimal. Ini terlihat dari disiplin sekolah yang masih kurang disiplin, baik dari tutornya dan juga dari warga belajarnya dan sarana sekolah yang diharapkan dapat mendukung berlangsungnya kegiatan belajar yang nyaman masih kurang memadai. Motivasi (Y) belum optimal. Ini terlihat dari sarana fisik sekolah yang masih kurang memadai dan peraturan yang diterapkan terlalu longsar sehingga warga belajar kurang termotivasi. Nilai signifikansi jalur pengaruh langsung diperoleh $t_{\text {hitung }}=3.54$, nilai ini lebih besar dari nilai $_{\text {tabel }}(0,05)=1.66$. Berdasarkan hasil tersebut dapat dinyatakan bahwa Pengaruh Lingkungan Sekolah (X) berpengaruh signifikan terhadap Motivasi warga belajar (Y). Nilai kooefisien jalur diketahui bahwa Pengaruh langsung Lingkungan (X) terhadap Motivasi (Y) mempunyai koefisien jalur sebesar 0.46. Dengan demikian Pengaruh Lingkungan $(X)$ berpengaruh signifikan terhadap Motivasi (Y).
\end{abstract}

Kata Kunci : Lingkungan dan Motivasi

\begin{abstract}
The purpose of this research is to find out how the condition of the school environment, how the motivation of citizens to learn, and how much influence the school environment $(X)$ on the motivation of citizens learning $(Y)$ Cipta Tunas Karya PKBM. By using a quantitative descriptive research method, the entire population of Cipta Tunas Karya learned were respondents with a total of 210 respondents, and the sample used was 90 sampling rondoms. The results in this study are the School Environment $(X)$ is not optimal. This can be seen from the school discipline that is still lacking in discipline, both from the tutor and also from the residents of learning and school facilities which are expected to support the ongoing learning activities that are still inadequate. Motivation $(Y)$ is not optimal. This can be seen from the physical facilities of schools which are still inadequate and the regulations applied are too loose so that citizens learn less motivated. Significance value of the direct influence path obtained $t_{\text {count }}=3.54$, this value is greater than the value of $t_{\text {table }}(0.05)=1.66$. Based on these results it can be stated that the Influence of School Environment $(X)$ has a significant effect on the motivation of learning citizens $(Y)$. The path coefficient value is known that the direct effect of the Environment $(X)$ on Motivation (Y) has a path coefficient of 0.46. Thus the influence of the environment $(X)$ has a significant effect on motivation $(Y)$.
\end{abstract}

Keywords : Environment and Motivation 


\section{PENDAHULUAN}

Pusat Kegiatan Belajar Masyarakat atau dikenal dengan sebutan PKBM merupakan sebuah lembaga pendidikan nonformal yang lahir dari kesadaran tentang betapa pentingnya kedudukan masyarakat dalam proses pembangunan. Oleh karena itu kehadiran PKBM merupakan sikap proaktif kelompok masyarakat sebagai agen perubahan (Change of Agent) untuk membukakan akses dan menjawab berbagai kebutuhan belajar masyarakat yang sesuai dengan situasi dan kondisi setempat. Lebih jauh lagi keberadaan PKBM di tengah-tengah masyarakat diharapkan mampu menjadi salah satu instrumen bagi terjadinya proses pembangunan melalui pemberdayaan potensi-potensi yang ada di masyarakat.

"Pusat Kegiatan Belajar Masyarakat (PKBM) sebagai lembaga yang tumbuh dari, oleh dan untuk masyarakat dituntut mampu menggerakkan dan memfasilitasi berbagai aktivitas bersama dalam pengembangan masyarakat. Agar harapan tersebut bisa dipenuhi oleh lembaga masyarakat, pada umumnya menuntut dua persyaratan : di satu pihak cukup mengakar dalam masyarakat dan dilain pihak, tanggap terhadap berbagai tuntutan perubahan dan pembaruan" (dikutif dalam Soetomo, 2006:16)

Dibentuknya PKBM sebagai pemicu yang bersifat sementara, masyarakat sendirilah yang selanjutnya memiliki kewenangan untuk mengembangkannya, karena itulah pendekatan dalam program PKBM ini disebut pendidikan berbasis masyarakat atau community-based education dengan harapan dapat dijadikan pijakan dan titik permulaan bagi semua komponen pembangunan untuk memberdayakan potensi-potensi yang ada di dalam masyarakat.

PKBM sebagai salah satu mitra kerja pemerintahdalammencerdaskankehidupan masyarakat melalui program-program pendidikan nonformal diharapkan mampu menumbuhkan masyarakat belajar (learning society) sehingga pada akhirnya akan meningkatkan kemandirian, keberdayaan dan inovatif dalam mencari informasi baru dalam rangka meningkatkan kehidupannya. Sebagai sebuah pusat pembelajaran (learning centre) PKBM dibangun atas dasar kebutuhan masyarakat dengan menitik beratkan swadaya, gotong-royong dan partisipasi masyarakat itu sendiri, terutama berkaitan dengan pentingnya peningkatan kemampuan, keterampilan atau kecerdasan anggota masyarakat (self actualization). Salah satu fungsi PKBM adalah sebagai lembaga penyelenggara kegiatan pembelajaran dan pemberdayaan masyarakat.

PKBM memiliki wadah organisasi di setiap daerah yang bernama Forum PKBM, pada Forum PKBM inilah silaturahmi antar pengelola PKBM itu berlangsung demi kemajuan PKBM itu sendiri. Forum PKBM Kota Tangerang kurang lebih memiliki 30 anggota dan forum ini dibentuk oleh pengelola PKBM yang ada di Kota Tangerang. Adapun salah satu dibentuknya forum ini adalah sebagai wadah PKBM yang ada di Kota Tangerang, untuk mempermudah pola kerja sebagai mitra pemerintah di bawah dinas pendidikan.

PKBM Cipta Tunas Karya sejak berdiri dan beroperasi sejak tahun 2010 terus berupaya melakukan perbaikan-perbaikan, diantaranya pembangunan gedung sebagai sarana penunjang kegiatan belajar. Walaupun gedung sudah ada akan tetapi sarana gedung itu sendiri masih kurang memadai seperti, ruang kelas yang sempit, pentilasi udara yang kurang dan yang lainnya. Dikarenakan warga belajar yang banyak maka mengakibatkan sempitnya ruang belajar dan kenyamanan belajarpun akan berkurang.

Lingkungan sekolah merupakan tempat para warga belajar melakukan aktivitas belajar. Lingkungan sekolah dapat membawa dampak positif dan negatif bagi warga belajar dalam rangka mencapai hasil yang maksimal. Lingkungan belajar yang kurang baik akan dapat menurunkan motivasi bagi warga belajar di dalam kegiatan belajar tersebut. Pada saat ini lingkungan belajar dapat didesain sedemikian rupa untuk menciptakan hubungan yang mengikat pekerja dalam lingkungannya. Di Kota Tangerang masih sedikit PKBM yang sudah memiliki gedung sendiri dan yang sudah memiliki gedung sendiripun gedungnya masih kurang memadai apalagi fasilitas yang lain yang menunjang jalannya kegiatan belajar mengajar, seperti ruang tutor, ruang lab, ruang belajar yang sempit, tempat istirahat yang 
tidak kondusif, kantin yang kurang nyaman dan lainnya.

Lingkungan yang baik "merupakan lingkungan yang aman, tenteram, bersih, tidak bising, terang dan bebas dari segala macam ancaman. Lingkungan yang kondusif akan membawa dampak baik bagi kelangsungan belajar, sebaliknya, lingkungan yang kurang kondusif akan membawa dampak negatif bagi kelangsungan warga belajar. Tutor yang diharapkan dapat menjadi teman belajar para warga belajar di PKBM masih ada yang terlambat datang pada waktu mengajar dan ada juga yang jarang masuk, sehingga mengakibatkan berdampak pada menurunnya motivasi warga belajar. Dari sekian banyaknya warga belajar yang ada di PKBM Cipta Tunas Karya, masih banyak sekali yang datang tidak tepat waktu, dan juga masih ada saja yang masuknya hanya di telpon sama pengelola atau ketika mau ujian saja.

Dari latar belakang di atas penulis tertarik untuk melakukan penelitian dengan judul : Pengaruh lingkungan terhadap motivasi warga belajar pada KBM Cipta Tunas Karya di Cipondoh Kota Tangerang.

Berbagai permasalahan yang di hadapi PKBM sangatlah kompleks, diantaranya adalah masalah motivasi warga belajar yang belum maksimal. Dan banyak faktor yang mempengaruhi dengan tingkat motivasi warga belajar, untuk lebih mengarahkan dan memfokuskan dari penelitian ini, penulis membatasi penelitian dengan hanya mengambil Lingkungan sekolah (X), dan motivasi warga belajar (Y).

\section{METODE}

Penelitian ini menggunakan deskriptif adalah metode yang digunakan oleh peneliti untuk mengambarkan fenomena yang terjadi pada PKBM Cipta Tunas Karya yang beralamat Jl. Ki Hajar Dewantoro Rt. 04/04 Kel Gondrong Cipondoh Kota Tangerang pada tahun pelajaran 2018/2019, adapun penelitian ini dapat diartikan sebagai proses pemecahan masalah yang diselidiki dengan melukiskan keadaan subyek dan obyek penelitian pada saat sekarang berdasarkan fakta-fakta yang tampak atau bagaimana adanya, adapun jenis yang digunakan dalam penelitian ini adalah jenis penelitian survei.

Jenis penelitian survei adalah "suatu cara penelitian deskriptif yang dilakukan terhadap sekumpulan objek yang biasanya cukup banyak dalam jangka waktu tertentu yang bersamaan. Tujuan survei adalah untuk membuat penilaian terhadap suatu kondisi dan penyelenggaraan suatu program di masa sekarang dan hasilnya digunakan untuk menyusun perencanaan perbaikan program tersebut."

Metode yang digunakan dalam penelitian ini adalah deskriptif kuantitatif yaitu "suatu bentuk penelitian yang berdasarkan data yang dikumpulkan selama penelitian secara sistematis mengenai fakta-fakta dan sifat-sifat dari obyek yang diteliti. Dalam penelitian ini penulis memperoleh data dengan menggunakan kuesioner yang telah diberi skor, dimana data tersebut nantinya akan dihitung secara statistik."

Populasi dalam penelitian ini adalah seluruh warga belajar yang terdaftar di PKBM Cipta Tunas Karya sebanyak 210 warga belajar baik dari program paket A setara SD, program paket $B$ setara SMP dan program paket C setara SMA pada pelajaran 2018/2019.

Adapun sampel yang digunakan dalam penelitian ini dengan menggunakan rondom sampling. Jumlah populasi sebanyak 210 warga belajar dengan sampel ditetapkan responden dari jumlah warga belajar yang ada PKBM Cipta Tunas Karya adalah 90 sampel berdasarkan slovin dengan penentuan jumlah sampel penelitian.

$S=\frac{\mathrm{N}}{\mathrm{N} \cdot \mathrm{d}^{2}+1}=\frac{210}{210.0,08^{2}+1}=89,59=90$

\section{Definisi Konseptual dan Operasional Variable}

1. Lingkungan sekolah

a. Definisi Konseptual

Lingkungan Sekolah - Lingkungan diartikan "sebagai kesatuan ruang suatu benda, daya, keadaan dan mahluk hidup termasuk manusia dan perilakunya yang mempengaruhi kelangsungan peri kehidupan dan kesejahteraan manusia serta mahluk hidup lainnya" (Munib, 2005:76). Sedangkan 
Sekolah adalah "wahana kegiatan dan proses pendidikan berlangsung. Di sekolah diadakan kegiatan pendidikan, pembelajaran dan latihan" (Tu'u, 2004:18). "Sekolah merupakan lembaga pendidikan formal yang sistematis melaksanakan program bimbingan, pengajaran, dan latihan dalam rangka membantu siswa agar mampu mengembangkan potensinya baik yang menyangkut aspek moral, spiritual, intelektual, emosional maupun social" (Syamsu Yusuf, 2001:54).

b. Operasional Variabel

Operasionalisasi dari penelitian ini adalah dengan mengukur semua indikator menggunakan skala Likers, dengan 5 jawaban, SS= Sangat Setuju (bobot nilai 5), ST= Setuju (bobot nilai 4), RG= Ragu-ragu (bobot nilai 3), TS= Tidak Setuju ((bobot nilai 2), STS= Sangat Tidak Setuju (bobot nilai 1).

c. Kisi-kisi kuisioner

\begin{tabular}{|c|l|c|c|c|}
\hline \multicolumn{5}{c}{ Tabel 1. Kisi-kisi Kuisioner Lingkungan Sekolah } \\
\hline \multirow{4}{*}{ VARIABEL } & \multicolumn{1}{|c|}{ INDIKATOR } & ITEM ANGKET & JUMLAH & ALAT UKUR \\
\hline \multirow{3}{*}{$\begin{array}{l}\text { Lingkungan } \\
\text { Sekolah }\end{array}$} & Disiplin Sekolah & $1,2,3,4,5$ & 5 & \\
\cline { 2 - 5 } & Relasi tutor dan WB & $6,7,8,9,10$ & 5 & $\begin{array}{l}\text { Angket } \\
\text { menggunakan } \\
\text { skala Likers }\end{array}$ \\
\cline { 2 - 5 } & Relasi WB dan WB & $11,12,13,14,15$ & 5 & \\
\cline { 2 - 5 } & Fasilitas Sekolah & $16,17,18,19,20$ & 5 & \\
\hline
\end{tabular}

2. Motivasi Warga Belajar

a. Definisi Konseptual

Motivasi menurut Munandar (2004) adalah "suatu proses dimana kebutuhan-kebutuhan mendorong seseorang untuk melakukan serangkaian kegiatan yang mengarah ke tercapainya tujuan tertentu." Bila kebutuhan telah terpenuhi maka akan dicapai suatu kepuasan. Sekelompok kebutuhan yang belum terpuaskan akan menimbulkan ketegangan, sehingga perlu dilakukan serangkaian kegiatan untuk mencari pencapaian tujuan khusus yang dapat memuaskan kelompok kebutuhan tadi, agar ketegangan menjadi berkurang".

b. Operasional Variabel

Operasionalisasi dari penelitian ini adalah dengan mengukur semua indikator menggunakan skala Likers, dengan 5 jawaban, SS=
Sangat Setuju (bobot nilai 5), ST= Setuju (bobot nilai 4), $\mathrm{RG}=$ Ragu-ragu (bobot nilai 3), TS= Tidak Setuju ((bobot nilai 2), STS= Sangat Tidak Setuju (bobot nilai 1).

c. Kisi-kisi kuisioner

\begin{tabular}{|c|c|c|c|c|}
\hline \multicolumn{5}{|c|}{ Tabel 2. Kisi-kisi Kuisioner Motivasi Warga Belajar } \\
\hline VARIABEL & INDIKATOR & ITEM ANGKET & JUMLAH & ALAT UKUR \\
\hline \multirow{4}{*}{$\begin{array}{l}\text { Motivasi } \\
\text { Warga } \\
\text { Belajar }\end{array}$} & Sarana Fisik & $1,2,3,4,5$ & 5 & \multirow{4}{*}{$\begin{array}{l}\text { Angket } \\
\text { menggunakan } \\
\text { skala Likers }\end{array}$} \\
\hline & Kebijksanaan & $6,7,8,9,10$ & 5 & \\
\hline & Peraturan & $11,12,13,14,15$ & 5 & \\
\hline & Hadiah & $16,17,18,19,20$ & 5 & \\
\hline
\end{tabular}

\section{HASIL dan PEMBAHASAN \\ Hasil}

Pengertian Lingkungan Sekolah terdiri dari 2 suku kata yaitu: 1). "Lingkungan diartikan sebagai kesatuan ruang suatu benda, daya, keadaan dan mahluk hidup termasuk manusia dan perilakunya yang mempengaruhi kelangsungan peri kehidupan dan kesejahteraan manusia serta mahluk hidup lainnya" (Munib, 2005:76). 2). Sekolah sebagai "wahana kegiatan dan proses pendidikan berlangsung. Di sekolah diadakan kegiatan pendidikan, pembelajaran dan latihan" (Tu’u, 2004:18). "Sekolah merupakan lembaga pendidikan formal yang sistematis melaksanakan program bimbingan, pengajaran, dan latihan dalam rangka membantu siswa agar mampu megembangkan potensinya baik yang menyangkut aspek moral, spiritual, intelektual, emosional maupun sosial" (Syamsu Yusuf, 2001:54).

Sedangkan lingkungan pendidikan adalah berbagai faktor yang berpengaruh terhadap pendidikan atau berbagai lingkungan tempat berlangsungnya proses pendidikan. Jadi lingkungan sekolah adalah kesatuan ruang dalam lembaga pendidikan formal yang memberikan pengaruh pembentukan sikap dan pengembangan potensi siswa.

\section{Faktor-faktor Dalam Lingkungan Sekolah}

Menurut Slameto (2003:64) faktor-faktor sekolah yang mempengaruhi belajar mencakup :

a. Metode mengajar

"Merupakan suatu cara atau jalan yang harus dilalui didalam mengajar. Metode mengajar 
dapat mempengaruhi belajar siswa. Metode mengajar guru yang kurang baik akan mempengaruhi belajar siswa yang tidak baik pula. Agar siswa dapat belajar dengan baik, maka metode mengajar harus diusahakan yang setepat, efisien dan efektif mungkin."

b. Kurikulum

"Diartikan sebagai sejumlah kegiatan yang diberikan kepada siswa. Kegiatan itu sebagian besar adalah menyajikan bahan pelajaran agar siswa menerima, menguasai dan mengembangkan bahan pelajaran itu. Kurikulum yang kurang baik akan berpengaruh tidak baik pula terhadap belajar."

c. Relasi guru dengan siswa

"Proses belajar mengajar terjadi antara guru dengan siswa. Proses ini dipengaruhi oleh relasi didalam proses tersebut. Relasi guru dengan siswa baik, membuat siswa akan menyukai gurunya, juga akan menyukai mata pelajaran yang diberikannya sehingga siswa berusaha mempelajari sebaik-baiknya.Guru yang kurang berinteraksi dengan siswa dengan baik menyebabkan proses belajarmengajar itu kurang lancar."

d. Relasi siswa dengan siswa

"Siswa yang mempunyai sifat kurang menyenangkan, rendah diri atau mengalami tekanan batin akan diasingkan dalam kelompoknya. Jika hal ini semakin parah, akan berakibat terganggunya belajar. Siswa tersebut akan malas untuk sekolah dengan berbagai macam alasan yang tidak-tidak. Jika terjadi demikian, siswa tersebut memerlukan bimbingan dan penyuluhan. Menciptakan relasi yang baik antar siswa akan memberikan pengaruh positif terhadap belajar siswa."

e. Disiplin sekolah

"Berkaitannya dengan kerajinan siswa dalam sekolah dan belajar. Kedisiplinan sekolah mencakup kedisiplinan guru dalam mengajar, pegawai sekolah dalam bekerja, kepala sekolah dalam mengelola sekolah, dan BP dalam memberikan layanan.

Seluruh staf sekolah yang mengikuti tata tertib dan bekerja dengan disiplin membuat siswa disiplin pula. Dalam proses belajar, disiplin sangat dibutuhkan untuk mengembangkan motivasi yang kuat. Agar siswa belajar lebih maju, maka harus disiplin di dalam belajar baik di sekolah, di rumah dan lain-lain.”

f. Alat pelajaran

"Berkaitan dengan cara belajar siswa karena alat pelajaran tersebut dipakai siswa untuk menerima bahan pelajaran dan dipakai guru waktu mengajar. Alat pelajaran yang lengkap dan tepat akan mempercepat penerimaan bahan pelajaran. Jika siswa mudah menerima pelajaran dan menguasainya, belajar akan lebih giat dan lebih maju. Mengusahakan alat pelajaran yang baik dan lengkap sangat dibutuhkan guna memperlancar kegiatan belajar-mengajar."

g. Waktu sekolah

"Merupakan waktu terjadinya proses belajar mengajar disekolah. Waktu sekolah akan mempengaruhi belajar siswa. Memilih waktu sekolah yang tepat akan memberikan pengaruh yang positif terhadap belajar. Sekolah di pagi hari adalah adalah waktu yang paling tepat di mana pada saat itu pikiran masih segar dan kondisi jasmani masih baik."

Dari uraian di atas, indikator-indikator dalam lingkungan sekolah adalah :

1. disiplin sekolah

2. relasi guru dengan siswa

3. relasi siswa dengan siswa

4. fasilitas sekolah

\section{Motivasi}

Menurut Moekijat dalam Malayu S.P. Hasibuan (2006) mengatakan "bahwa motif adalah suatu pengertian yang mengandung semua alat penggerak alasan-alasan atau dorongan-dorongan dalam diri manusia yang menyebabkan ia berbuat sesuatu". Hal ini senada dengan Tim Penyusun Kamus Besar Bahasa Indonesia (2008), mengartikan "motivasi sebagai dorongan yang timbul pada diri seseorang secara sadar atau tidak sadar untuk melakukan suatu tindakan dengan tujuan tertentu". Sedangkan Sardiman (2007) mendefinisikan "bahwa motivasi sebagai serangkaian usaha untuk menyediakan kondisikondisi tertentu, sehingga seseorang mau dan 
ingin melakukan sesuatu dan bila ia tidak suka, maka akan berusaha untuk meniadakan atau mengelakkan perasaan tidak suka itu. Jadi motivasi itu dapat dirangsang oleh faktor dari luar tetapi motivasi itu adalah tumbuh didalam diri seseorang".

Motivasi warga belajar merupakan motivasi yang terjadi pada situasi dan lingkungan yang terdapat pada suatu organisasi atau lembaga. Pada dasarnya manusia selalu menginginkan hal yang baik-baik saja, sehingga daya pendorong atau penggerak yang memotivasi semangat dalam belajar tergantung dari harapan yang akan diperoleh mendatang. Jika harapan itu dapat menjadi kenyataan maka seseorang akan cenderung meningkatkan semangat belajar. Tetapi sebaliknya jika harapan itu tidak tercapai akibatnya seseorang cenderung menjadi malas.

Motivasi menurut Munandar (2004) adalah "suatu proses dimana kebutuhan-kebutuhan mendorong seseorang untuk melakukan serangkaian kegiatan yang mengarah ketercapainya tujuan tertentu. Bila kebutuhan telah terpenuhi maka akan dicapai suatu kepuasan. Sekelompok kebutuhan yang belum terpuaskan akan menimbulkan ketegangan, sehingga perlu dilakukan serangkaian kegiatan untuk mencari pencapaian tujuan khusus yang dapat memuaskan kelompok kebutuhan tadi, agar ketegangan menjadi berkurang".

Sadili Samsudin (2006:282) mengemukakan "bahwa motivasi kerja adalah sesuatu yang menimbulkan dorongan atau semangat kerja yang dipengaruhi oleh beberapa faktor, antara lain atasan, sarana fisik, kebijaksanaan, peraturan, imbalan jasa uang dan non uang, jenis pekerjaan dan tantangan".

Malayu S.P. Hasibuan (2005:143) menyatakan "bahwa motivasi kerja adalah pemberian daya penggerak yang menciptakan kegairahan kerja seseorang agar mereka mau bekerja sama, bekerja efektif, dan terintegrasi dengan segala daya upayanya untuk mencapai kepuasan."

\section{Faktor-Faktor Yang}

Mempengaruhi Motivasi Kerja

Faktor-faktor yang mempengaruhi motivasi kerja menurut Suster meister dalam Djatmiko, Yayat Hayati (2002:67) yaitu:

1) Kondisi lingkungan kerja

2) Kondisi social lingkungan kerja

3) Keterpenuhan kebutuhan dasar individu Sedangkan menurut Pasualang, Harbani (2010:152) faktor-faktor yang mempengaruhi motivasi kerja yaitu:

1). Faktor eksteren

(a) Kepemimpinan

(b) Lingkungan kerja yang menyenangkan

(c) Komposisi yang memadai

(d) Adanya penghargaan akan prestasi

(e) Status dan tanggung jawab

2). Faktor interen
(a) Kematangan pribadi
(b) Tingkat pendidikan
(c) Keinginan dan harapan pribadi
(d) Kebutuhan terpenuhi
(e) Kelemahan dan keborosan
(f) Kepuasan kerja

\section{Profil Lembaga}

1. Nama Lembaga : PKBM CIPTA TUNAS KARYA

2. Nilem : P9926357

3. Alamat Lengkap : Jl.Ki Hajar Dewantoro Rt. 04/04, Kel Gondrong, Kec. Cipondoh, Kota Tangerang

4. No. Tlp. /HP : 081286229296

5. Nama Ketua : KUSUMA WIJAYA, S.Pd

6. Nama Bank : Bank BRI Cabang Cipondoh

7. No. Rek.A.n Lembaga : 0818-01-034116-53-5

8. Pemegang Rek. Bank: 1. Kusuma Wijaya, S.Pd; 2. Khoiriah, S.Pd

9. NPWP : 03.028.667.8-416.000

10. Program yang dilaksanakan: Pendidikan Kesetaraan : $(\sqrt{ })$ Paket A $(\sqrt{ })$ Paket B $(\sqrt{ })$ Paket C. Program lain : 1. Bimbingan Belajar; 2. PAUD

Data Tutor dan Peserta Didik Pendidikan Kesetaraan :

\begin{tabular}{|c|l|c|c|c|c|}
\hline \multicolumn{6}{|c|}{ Tabel 3. Data Tutor PKBM Cipta Tunas Karya } \\
\hline NO & PROGRAM & PAKET A & PAKET B & PAKET C & KET \\
\hline 1 & Tutor Laki-Laki & 2 & 4 & 4 & \\
\hline 2 & Tutor Perempuan & 3 & 4 & 5 & \\
\hline \multicolumn{7}{|c|}{ Jumlah } & 5 & 8 & 9 & \\
\hline
\end{tabular}




\begin{tabular}{|c|c|c|c|c|c|}
\hline \multicolumn{7}{|c}{$\begin{array}{c}\text { Tabel 4. Data Peserta Didik Pendidikan } \\
\text { Kesetaraan PKBM Cipta Tunas Karya }\end{array}$} \\
\begin{tabular}{|c|c|c|c|c|c|}
\hline NO & PROGRAM & PAKET A & PAKET B & PAKETC & KET \\
\hline 1 & Peserta Didik Laki-Laki & 11 & 30 & 55 & \\
\hline 2 & Peserta Didik Perempuan & 23 & 22 & 49 & \\
\hline \multicolumn{7}{|c|}{ Jumlah } & 34 & 72 & 104 & 210 \\
\hline
\end{tabular}
\end{tabular}

\section{Maksud dan Tujuan}

1. Umum

Memberi kesempatan kepada warga masyarakat Kota Tangerang untuk memperoleh pendidikan dalam rangka mewujudkan keadilan pendidikan disetiap lapisan masyarakat.

2. Khusus

Mengembangkan dan meningkatkan peran PKBM Cipta Tunas Karya sebagai salah satu lembaga penyelenggara Pendidikan Luar Sekolah (PLS) Kota Tangerang dengan program Paket A, paket B dan Paket C.

a. Memberikan kesempatan yang lebih luas pada masyarakat khususnya generasi muda putus sekolah dan anak tidak mampu.

b. Untuk dapat menyelesaikan jenjang Pendidikan yang belum pernah ditempuh.

c. Mendorong agar setiap SDM berupaya melakukan pengembanganadiri melalui pendidikan yang dimiliki.

d. Meningkatkan pengalaman belajar yang mandiri, kreatif dan produktif.

e. Memberikan bekal pengetahuan, kemampuan dan sikap dasar yang memungkinkan warga belajar mengikuti pendidikan lanjutan diperguruan tinggi.

\section{Sasaran dan Hasil Yang Diharapkan}

Sasaran program Paket A, Paket B dan Paket $\mathrm{C}$ ini adalah :

- Warga masyarakat Kota Tangerang khususnya generasi muda Kota Tangerang yang belum menempuh pendidikan.

- Warga masyarakat yang kurang mampu.

- Putus sekolah menengah pertama atau Droup Out (DO).

- Tidak dapat sekolah karena karena letak sekolah dan karena sudah terjun ke masyarakat, bekerja dan lain-lain.

Hasil yang diharapkan setelah mengikuti program Paket A, Paket B dan Paket C adalah :

1. Memiliki kesadaran yang tinggi tentang pendidikan untuk dirinya sendiri.

2. Memiliki pengetahuan setara dengan sekolah formal.

3. Memperoleh kesempatan untuk melanjutkan ke jenjang berikutnya.

\section{Variabel Pengaruh Lingkungan Sekolah (X)}

Variabel Pengaruh Lingkungan Sekolah (X) potensi, pengumpulan datanya menggunakan kuesioner yang diadaptasi dari konstruk teori Lingkungan Sekolah sebanyak 19 butir pernyataan dan diisi langsung oleh Warga belajar, masing-masing pernyataan mempunyai 5 pilihan jawaban dengan opsi penilaian 1 (satu) untuk nilai terendah kemudian berturut-turut 2, 3, 4, dan paling tinggi bernilai 5 .

Berdasarkan pengumpulan data lapangan dan analisis data pada variabel Lingkungan Sekolah (X) diperoleh hasil nilai terendah, nilai tertinggi, rata-rata, simpangan baku/standar deviasi, modus dan median seperti berikut:

\begin{tabular}{|c|c|c|}
\hline \multicolumn{2}{|c|}{ Tabel 5. Hasil Analisis Deskriptiflingkungan Sekolah (X) } \\
\hline NO & \multicolumn{1}{|c|}{ URAILAI } \\
\hline 1 & Banyak Responden & 90 \\
\hline 2 & Jumlah Butir Soal & 19 \\
\hline 3 & Jumlah Skor Variabel & 6,002 \\
\hline 4 & Nilai Tertinggi & 95 \\
\hline 5 & Nilai Terendah & 30 \\
\hline 6 & Rata-Rata (M) & 66.69 \\
\hline 7 & Simpangan Baku (SD) & 13.46 \\
\hline 8 & Rentang (R) & 65 \\
\hline 9 & Banyak Kelas & 10 \\
\hline 10 & Interval Kelas & 7 \\
\hline 11 & Modus (Mo) & 62 \\
\hline 12 & Median (Me) & 68.50 \\
\hline
\end{tabular}

Nilai Hasil analisis tersebut di atas dapat dijelaskan sebagai berikut:

Data yang didapat dari lapangan data terendah adalah 30 dan tertinggi 95 Nilai tersebut berkriteria cukup baik sampai dengan sangat baik.

a. Nilai rata-rata (mean) bernilai 66.69 nilai tersebut terletak pada posisi kriteria baik. Nilai ini memberikan gambaran bahwa 
Lingkungan Sekolah (X) belum optimal. Sedangkan posisi yang diharapkan sampai pada tingkat yang sangat baik.

b. Nilai Simpangan Baku. Hasil perhitungan diperoleh nilai sebesar 13.46, nilai tersebut mempunyai arti variasi data pada variabel Lingkungan Sekolah (X) lebih lebar, hal ini didukung dengan data rentang nilai sebesar 65 masih dalam batas toleran pada jumlah data 90 .

c. Nilai Modus atau data sering muncul mempunyai nilai 62. Nilai tersebut mempunyai kriteria baik. Nilai ini sedikit di dibawah nilai rata-rata. Hal ini menunjukkan bahwa banyaknya data di bawah rata-rata lebih kecil dibandingkan dengan banyaknya data di bawah rata-rata.

d. Nilai Median atau nilai tengah sebesar 68.50 dilihat pada posisi terletak sedikit lebih rendah dibandingkan dengan rata-rata nilai (mean). Nilai ini menunjukkan bahwa nilai data di atas sedikit lebih kecil dibandingkan dengan nilai data di bawah rata-rata.

e. Pengelompokan data/klasifikasi. Berdasarkan jumlah responden 90. Hasil perhitungan jumlah tersebut dikelompokkan menjadi 10 kelas dengan panjang kelas 7. Distribusi frekuensi per kelas sebagai berikut:

Tabel 6. Distribusi Frekuensi Lingkungan Kerja (X)

\begin{tabular}{|c|c|c|c|c|}
\hline KELAS & \multicolumn{2}{|c|}{ INTERVAL } & FREQUENCY & FREQUENCY RELATIVE \\
\hline 1 & 30 & 36 & 1 & 1.11 \\
\hline 2 & 37 & 43 & 0 & - \\
\hline 3 & 44 & 51 & 5 & 5.56 \\
\hline 4 & 52 & 58 & 13 & 14.44 \\
\hline 5 & 59 & 65 & 4 & 4.44 \\
\hline 6 & 66 & 72 & 15 & 16.67 \\
\hline 7 & 73 & 80 & 22 & 24.44 \\
\hline 8 & 81 & 87 & 14 & 15.56 \\
\hline 9 & 88 & 94 & 14 & 15.56 \\
\hline 10 & 95 & 101 & 2 & 2.22 \\
\hline
\end{tabular}

Berdasarkan data di atas maka dapat dijelaskan bahwa: Nilai tertinggi frekuensinya berada pada kelas 7 yaitu sebesar 22 sedangkan nilai yang rendah pada kelas 2. Frekuensi masing-masing kelas menunjukkan bahwa kelas 2 sedikit dan naik pada kelas 3 dan puncaknya pada kelas 7. Kemudian mengalami penurunan di kelas 8 hingga kelas 10. Hal ini menunjukkan bahwa penyebaran frekuensi Lingkungan Sekolah (X) umumnya berada pada tingkat rata-rata baik yaitu sebesar $66.69 \%$. Sedangkan dari 90 warga belajar yang memiliki kepribadian rendah sebesar $30 \%$ dan warga belajar yang memiliki kepribadian tinggi sebesar 95\%. Lebih jelas penyebaran data variabel Lingkungan Sekolah (X) dapat dilihat pada gambar histogram dibawah ini.

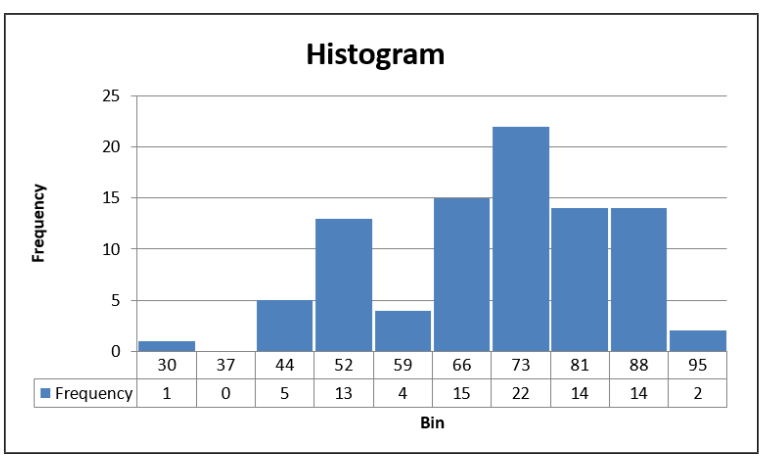

Gambar 1. Histogram Distribusi Frekuensi Lingkungan Sekolah (X)

Berdasarkan gambar histogram di atas terlihat bahwa bentuk histogram di setiap kelas jika dihubungkan membentuk suatu kurva dengan posisi puncak di kelas 7 . Bentuk tersebut cenderung menunjukkan distribusi data normal.

\section{Variabel Pengaruh Motivasi Warga Belajar (Y)}

Variabel Motivasi Kerja (Y1), pengumpulan datanya menggunakan kuesioner yang diadaptasi dari konstruk teori Motivasi sebanyak 19 butir pernyataan dan diisi langsung oleh warga belajar, masing-masing pernyataan mempunyai 5 pilihan jawaban dengan opsi penilaian 1 (satu) untuk nilai terendah kemudian berturut-turut 2,3,4, dan paling tinggi bernilai 5 .

Berdasarkan pengumpulan data lapangan dan analisis data pada variabel Motivasi (Y) diperoleh hasil nilai terendah, nilai tertinggi, ratarata, simpangan baku/standar deviasi, modus dan median seperti berikut:

\begin{tabular}{|c|c|c|}
\hline NO & URAIAN & NILAI \\
\hline 1 & Banyak Responden & 90 \\
\hline 2 & Jumlah Butir Soal & 19 \\
\hline 3 & Jumlah Skor Variabel & 6,234 \\
\hline 4 & Nilai Tertinggi & 94 \\
\hline
\end{tabular}




\begin{tabular}{|c|l|c|}
\hline 5 & Nilai Terendah & 41 \\
\hline 6 & Rata-Rata (M) & 69.27 \\
\hline 7 & Simpangan Baku (SD) & 14.39 \\
\hline 8 & Rentang (R) & 53 \\
\hline 9 & Banyak Kelas & 10 \\
\hline 10 & Interval Kelas & 6 \\
\hline 11 & Modus (Mo) & 69 \\
\hline 12 & Median (Me) & 70 \\
\hline
\end{tabular}

Nilai Hasil analisis tersebut di atas dapat dijelaskan sebagai berikut:

Data yang didapat dari lapangan data terendah adalah 41 dan tertinggi 94 . Nilai tersebut berkriteria cukup baik sampai dengan sangat baik.

a. Nilai rata-rata (mean) bernilai 69.27 nilai tersebut terletak pada posisi kriteria baik. Nilai ini memberikan gambaran bahwa Motivasi (Y) belum optimal. Sedangkan posisi yang diharapkan sampai pada tingkat yang sangat baik.

b. Nilai Simpangan Baku. Hasil perhitungan diperoleh nilai sebesar 14.39, nilai tersebut mempunyai arti variasi data pada variabel 69.27 lebih lebar, hal ini didukung dengan data rentang nilai sebesar 53 masih dalam batas toleran pada jumlah data 90 .

c. Nilai Modus atau data sering muncul mempunyai nilai 69. Nilai tersebut mempunyai kriteria baik. Nilai ini sedikit di bawah nilai rata-rata. Hal ini menunjukkan bahwa banyaknya data di bawah rata-rata lebih kecil dibandingkan dengan banyaknya data di bawah rata-rata.

d. Nilai Median atau nilai tengah sebesar 70 dilihat pada posisi terletak sedikit lebih tinggi dibandingkan dengan rata-rata nilai (mean). Nilai ini menunjukkan bahwa nilai data di atas sedikit lebih besar dibandingkan dengan nilai data di bawah rata-rata.

e. Pengelompokan data/klasifikasi. Berdasarkan jumlah responden 90. Hasil perhitungan jumlah tersebut dikelompokkan menjadi 10 kelas dengan panjang kelas 6. Distribusi frekuensi per kelas sebagai berikut:

\begin{tabular}{|c|c|c|c|c|}
\hline \multicolumn{5}{|c|}{ Tabel 8. Distribusi Frekuensi Motivasi Warga Belajar (Y) } \\
\hline KELAS & \multicolumn{2}{|c|}{ INTERVAL } & FREQUENCY & FREQUENCY RELATIVE \\
\hline 1 & 41 & 46 & 1 & 1.11 \\
\hline 2 & 47 & 52 & 5 & 5.56 \\
\hline
\end{tabular}

\begin{tabular}{|c|c|c|c|c|}
\hline 3 & 53 & 58 & 9 & 10.00 \\
\hline 4 & 59 & 64 & 10 & 11.11 \\
\hline 5 & 65 & 69 & 10 & 11.11 \\
\hline 6 & 70 & 75 & 11 & 12.22 \\
\hline 7 & 76 & 81 & 11 & 12.22 \\
\hline 8 & 82 & 87 & 16 & 17.78 \\
\hline 9 & 88 & 93 & 9 & 10.00 \\
\hline 10 & 94 & 99 & 8 & 8.89 \\
\hline
\end{tabular}

Berdasarkan data diatas maka dapat dijelaskan bahwa: Nilai tertinggi frekuensinya berada pada kelas atas atau kelas 8 yaitu sebesar 16 sedangkan nilai yang rendah pada kelas 1 . Frekuensi masingmasing kelas menunjukkan bahwa kelas 1 sedikit dan naik pada kelas 2 dan puncaknya pada kelas 8 , kemudian mengalami penurunan di kelas 9 hingga 10. Hal ini menunjukkan bahwa penyebaran frekuensi Motivasi (Y) umumnya berada pada tingkat rata-rata baik yaitu sebesar $69.16 \%$. Sedangkan dari 90 warga belajar yang memiliki kepribadian rendah sebesar $41 \%$ dan warga belajar yang memiliki kepribadian tinggi sebesar 94\%. Lebih jelas penyebaran data variabel Motivasi (Y) dapat dilihat pada gambar histogram di bawah ini.

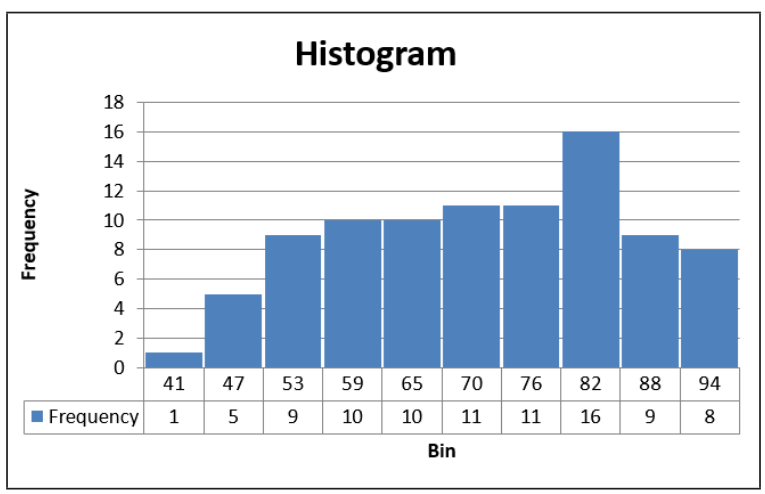

Gambar 2. Histogram Distribusi Frekuensi Motivasi Warga Belajar (Y)

Berdasarkan gambar histogram di atas terlihat bahwa bentuk histogram di setiap kelas jika dihubungkan membentuk suatu kurva dengan posisi puncak di kelas 8. Bentuk tersebut cenderung menunjukkan distribusi data normal.

Pengaruh Lingkungan (X) dengan Motivasi (Y)

Pengujian dilakukan dengan menggunakan teknik analisis regresi sederhana. Analisis regresi sederhana antara Lingkungan (X) atas Motivasi (Y) menghasilkan persamaan regresi $\mathrm{Y}_{1}=\mathrm{a}_{1}+\mathrm{b}_{1}$. $\mathrm{X}_{2}=23.90+0.68 \mathrm{X}_{2}$ nilai tersebut mempunyai arti 
bahwa jika variabel Kompetensi naik satu satuan maka variabel Motivasi (Y) akan naik sebesar $68 \%$ pada konstanta 23.90. Rangkuman hasil perhitungan linearitas dan uji keberartian regresi ditunjukkan pada tabel Anava sebagai berikut.

Tabel 8. Tabel Anava untuk Uji Signifikansi Regresi
Lingkungan (X) dengan Motivasi (Y)
\begin{tabular}{|c|c|c|c|c|c|c|}
\hline Sumber Varians & db & JK & RJK & F $_{\text {mutug }}$ & \multicolumn{2}{|c|}{$\mathbf{F}_{\text {tboal }}$} \\
\hline Total & & $18,433.60$ & & & $\alpha=0,01$ & $\alpha=0,05$ \\
\hline Regresi (b/a) & 89 & $7,465.68$ & $7,465.68$ & 59.90 & & \\
\hline Sisa & 188 & $10,967.92$ & 124.54 & & & \\
\hline
\end{tabular}

Keterangan:

** : Regresi sangat signifikan

$$
\left(\mathrm{F}_{\mathrm{h}}=59.90>\mathrm{F}_{\mathrm{t}}(0,05)=3,92\right)
$$

$\mathrm{db}:$ derajat bebas

JK : Jumlah Kuadrat

RJK : Rerata Jumlah Kuadrat

Hasil perhitungan uji keberartian regresi diperoleh harga $\mathrm{F}_{\text {hitung }}$ sebesar 57.60. Jika dibandingkan dengan harga $\mathrm{F}_{\text {tabel }}$ dengan $\mathrm{db}$ pembilang = 1 dan penyebut $=\mathrm{db}$ sisa yaitu 88 , pada taraf signifikansi 0,05, diperoleh nilai sebesar 3,92 maka dapat diketahui bahwa nilai $\mathrm{F}_{\text {hitung }}>\mathrm{F}_{\text {tabel }}$ Dari hasil tersebut di atas dapat disimpulkan bahwa terdapat hubungan yang signifkan dan berbentuk persamaan regresi linear Lingkungan (X) dengan Motivasi (Y).

Koefisien korelasi sederhana $\left(\mathrm{r}_{14}\right)$ antara Lingkungan (X) dengan Motivasi (Y) diperoleh nilai sebesar 0.64. Hasil hitung pengujian keberartian korelasi dengan menggunakan uji-t menghasilkan $\mathrm{t}_{\text {hitung }}=3.54$. Sedangkan nilai tabel pada daftar distribusi t untuk $\mathrm{db}=88$ dan taraf signifikasi 0,05 diperoleh $t_{\text {tabel }}$ sebesar 1,66. Dari hasil tersebut dapat diketahui bahwa nilai $\mathrm{t}_{\text {hitung }}>\mathrm{t}_{\text {tabel }}$ sehingga dapat disimpulkan bahwa antara Lingkungan (X) dengan Motivasi (Y) menunjukkan koefisien korelasi sangat signifikan.

Hasil perhitungan koefisien determinasi korelasi diperoleh nilai 0.64 , memberi arti bahwa sekitar 64\% variasi yang terjadi pada Motivasi (Y) dapat dijelaskan oleh Lingkungan (X). Penjelasan tersebut dapat dilakukan dengan menggunakan persamaan regresi seperti di atas.

\section{Pengujian Hipotesis}

Pengaruh Lingkungan (X) terhadap Motivasi
(Y).

Hipotesis Statistik:

$\mathrm{H}_{0}: \mathrm{p}_{32} \leq 0$

$\mathrm{H}_{1}: \mathrm{p}_{32}>0$

Dari hasil perhitungan diperoleh nilai koefisien jalur $\mathrm{p}_{32}=0.39$ dengan nilai $\mathrm{t}_{\text {hitung }}=3.54$. Nilai pada $t_{\text {tabel }}$ dengan tingkat signifikansi 0,05 dan jumlah responden $(n)=90$ diperoleh angka $t_{\text {tabel }}$ $=1,66$. Berdasarkan nilai estimasi koefisien jalur dan nilai $t_{\text {hitung }}$ pengaruh langsung Lingkungan (X) terhadap Motivasi (Y) meskipun tidak terlalu tinggi sebesar 0.39 namun tetap signifikan terbukti dengan $\mathrm{t}_{\text {hitung }}=3.54>\mathrm{t}_{\text {tabel }}=1,66$, dengan demikian hipotesis 5 yang menduga terdapat pengaruh langsung Lingkungan (X) terhadap motivasi (Y) dapat diterima. Hal ini mencerminkan bahwa jika dimensi Lingkungan (X) makin terbuka, ramah, intelektualitasnya tinggi, dan emosionalnya stabil maka motivasi (Y) akan meningkat. Disamping pengaruh langsung kausal dari keempat variabel tersebut juga akan menimbulkan pengaruh tidak langsung yaitu:

\section{Pembahasan}

\section{Kondisi Lingkungan Sekolah PKBM}

Data yang didapat dari lapangan data terendah adalah 30 dan tertinggi 95 Nilai tersebut berkriteria cukup baik sampai dengan sangat baik. Nilai rata-rata berjumlah 66.69 , nilai tersebut terletak pada posisi kriteria baik. Nilai ini memberikan gambaran bahwa Lingkungan Sekolah (X) belum optimal. Ini terlihat dari disiplin sekolah yang masih kurang disiplin baik dari tutornya dan juga dari warga belajarnya dan sarana sekolah yang masih kurang memadai, Sedangkan posisi yang diharapkan sampai pada tingkat yang sangat baik.

\section{Motivasi Warga Belajar}

Data yang didapat dari lapangan data terendah adalah 41 dan tertinggi 94 . Nilai tersebut berkriteria cukup baik sampai dengan sangat baik. Nilai rata-rata berjumlah 69.27 nilai tersebut terletak pada posisi kriteria baik. Nilai ini memberikan gambaran bahwa Motivasi (Y) belum optimal. Ini terlihat dari sarana fisik sekolah yang masih kurang memadai dan peraturan yang 
diterapkan terlalu longsar sehingga warga belajar kurang termotivasi. Sedangkan posisi yang diharapkan sampai pada tingkat yang sangat baik.

\section{Pengaruh Lingkungan (X) terhadap Motivasi (Y)}

Berdasarkan hasil analisis regresi dan korelasi diketahui bahwa Lingkungan (X) dengan Motivasi (Y) mempunyai hubungan membentuk persamaan regresi. Hubungan tersebut berbentuk garis linear yang dibuktikan dengan uji linearnitas diperoleh $\mathrm{F}_{\text {hitung }}=59.90>$ dari $\mathrm{F}_{\text {tabel }}=$ 3,96. Uji keberartian regresi diperoleh nilai keberatian $\mathrm{F}_{\text {hitung }}=59.90$ jauh di atas nilai $\mathrm{F}_{\text {tabel }}=$ 3,96 dengan nilai koefisien korelasi sebesar 0.64. Hasil tersebut memberikan arti bahwa setiap peningkatan Lingkungan Sekolah (X) satu satuan maka Motivasi Warga belajar (Y) akan meningkat sebesar $68 \%$ pada konstanta 23.90 .

Nilai signifikansi jalur pengaruh langsung diperoleh $\mathrm{t}_{\text {hitung }}=3.54$, nilai ini lebih besar dari nilai $\mathrm{t}_{\text {tabel }}(0,05)=1.66$. Berdasarkan hasil tersebut dapat dinyatakan bahwa Pengaruh Lingkungan Sekolah (X) berpengaruh signifikan terhadap Motivasi warga belajar (Y). Nilai kooefisien jalur diketahui bahwa Pengaruh langsung Lingkungan (X) terhadap Motivasi (Y) mempunyai koefisien jalur sebesar 0.46. Dengan demikian Pengaruh Lingkungan (X) berpengaruh signifikan terhadap Motivasi (Y).

\section{SIMPULAN}

Lingkungan Sekolah (X) belum optimal. Ini terlihat dari disiplin sekolah yang masih kurang disiplin, baik dari tutornya dan juga dari warga belajarnya dan sarana sekolah yang diharapkan dapat mendukung berlangsungnya kegiatan belajar yang nyaman masih kurang memadai. Motivasi (Y) belum optimal. Ini terlihat dari sarana fisik sekolah yang masih kurang memadai dan peraturan yang diterapkan terlalu longsar sehingga warga belajar kurang termotivasi. Nilai signifikansi jalur pengaruh langsung diperoleh $t_{\text {hitung }}$ $=3.54$, nilai ini lebih besar dari nilai $t_{\text {tabel }}(0,05)$ $=1.66$. Berdasarkan hasil tersebut dapat dinyatakan bahwa Pengaruh Lingkungan Sekolah (X) berpengaruh signifikan terhadap Motivasi warga belajar (Y). Nilai kooefisien jalur diketahui bahwa Pengaruh langsung Lingkungan (X) terhadap Motivasi (Y) mempunyai koefisien jalur sebesar 0.46. Dengan demikian Pengaruh Lingkungan (X) berpengaruh signifikan terhadap Motivasi $(\mathrm{Y})$.

\section{PENGHARGAAN}

Penghargaan ini saya sampaikan kepada warga belajar dan PKBM Cipta Tunas Karya.

\section{DAFTAR PUSTAKA}

Amsyari. (1986). Prinsip-Prinsip Masalah Pencemaran Lingkungan. Jakarta: Ghalia.

Sardiman,A.M.(2007). Interaksi dan Motivasi Belajar Mengajar. Jakarta: Raja Grafindo Persada.

Rusyan, A.T. (1990). Profesionalisme Tenaga Kependidikan. Bandung: Yayasan Karya.

Depdiknas. (2003). Undang-undang Republik Indonesia Nomor 20 tahun 2003 Tentang Sistem Pendidikan Nasional. Jakarta

Danang, S. (2012). Manajemen Sumber Daya Manusia. Yogyakarta: Caps.

Djamarah, \& Bahri, S. (2000). Guru dan Anak Didik dalam Interaksi Edukatif. Jakarta: Rineka Cipta

Djatmiko, Y. H. (2002). Perilaku Organisasi. Bandung : Alfabeta.

Handoko, T. H. (2001). Manajemen Personalia dan Sumber Daya Manusia. Edisi Kedua Cetakan Kelima belas. BPFE: Jogyakarta.

Tilaar, H.A.R. (2002). Manajemen pendidikan Nasional. Bandung : Cipta/ Rosada.

Handoko, T. Hani. (2003). Manajemen. Cetakan Kedelapan belas. J iiiii BPFE Yogyakarta, Yogyakarta.

Mardiana. (2005). Manajemen Produksi. Badan Penerbit IPWI, Jakarta.

Malayu S.P. Hasibuan, (2006). Manajemen Sumber daya Manusia. Jakarta.

Munandar.(2004). Pengembangan kreativitas Anak Berbakat. Jakarta : Rineka Cipta.

Munandar, Ashar Sunyoto. (2001). Psikologi Industri dan Organisasi. Jakarta :

Moekijat. (2002). Dasar-Dasar Motivasi. Bandung 
: Pionir Jaya.

Mulyasa. (2004). Menjadi Kepala Sekolah Profesional dalam Konteks Menyukseskan $M B S$ \& KBK. Bandung: Remaja Rosdakarya

Nazir, A .(2019). Pengaruh Pelatihan dan Displin Terhadap Kinerja Karyawan PT Surya Mustika Nusantara. Jurnal Mandiri Vol.3 No.1.150-169

Nanang, F. (2000). Landasan Manajemen Pendidikan. Bandung, Remaja Rosda karya.

Purwanto, N.(1988). Psikologi Pendidikan Cet. Ke IV. Bandung, Remadja Karya.

Republik Indonesia. (2005). Peraturan Pemerintah

PP) Nomor 19 Tahun 2005 Tentang Badan Standar Nasional Pendidikan (BSNP). Jakarta: Menteri Hukum dan HAM

Republik Indonesia. (2003). Undang-Undang Republik Indonesia Nomor 20 Tahun 2003 Tentang Sistem Pendidikan Nasional. Jakarta: Sekretariat Negara

Republik Indonesia. (2005). Undang-Undang Republik Indonesia Nomor 14 Tahun 2005 Tentang Guru dan Dosen. Jakarta: Sekretariat
Negara

Riadi, E.(2016). Analisis lisrel jalur. Bandung : Alfabeta

Sarwono. P. (1998). Pengukuran Efektivitas Kerja Pegawai. Andi Offset. Jogyakarta.

Sardiman, A.M. (2000). Interaksi dan Motivasi Belajar Mengajar. Jakarta: Raja Grafindo Persada.

Sarwono, S. W. (2005). Psikologi Lingkungan. Jakarta: Gramedia Grasindo.

Sergiovanni, T.J. (1991). The principalship : A reflective practice perspective ( 2 nd ed). Boston: Allyn and Bacon.

Sihombing, S. (2004). Manajemen Sumber Daya Manusia. Jakarta: Balai Pustaka.

Sedarmayanti. (2009). Sumber Daya Manusia dan Produktivitas Kerja. Bandung: CVMandar Maju.

Slameto. (2003). Belajar dan Faktor-faktor yang Mempengaruhinya. Jakarta: Rineka Cipta.

Tu'u,T.(2004). Peran Disiplin pada Perilaku dan Prestasi Siswa. Jakarta : Rineka Cipta. 